\title{
Committee for managing the risk by Faults and Cracks due to subsidence in Aguascalientes State, México
}

\author{
Jesús Pacheco-Martínez ${ }^{1}$, Martín Hernández-Marín ${ }^{1}$, Mario E. Zermeño-de-León ${ }^{1}$, \\ Norma González-Cervantes ${ }^{1,2}$, José A. Ortiz-Lozano ${ }^{1}$, Omar Vázquez-Gloria ${ }^{3}$, and \\ Armando Roque-Cruz ${ }^{4}$ \\ ${ }^{1}$ Departamento de Ingeniería Civil, Univ, Aut. de Aguascalientes, Aguascalientes, 20131, México \\ ${ }^{2}$ Centro de Geociencias, Universidad Nacional Autónoma de México, Querétaro, 76230, México \\ ${ }^{3}$ Centro de Ciencias del Diseño y de la Construcción, Univ, Aut. de Aguascalientes, \\ Aguascalientes, 20131, México \\ ${ }^{4}$ SEGUOT, Gobierno del estado de Aguascalientes, Aguascalientes, 20131, México \\ Correspondence: Jesús Pacheco-Martínez (jesus.pacheco@edu.uaa.mx)
}

Published: 22 April 2020

\begin{abstract}
Land subsidence due to groundwater withdrawal has been developing in the Aguascalientes Valley since the 1980's. Even though the affected area is close to $900 \mathrm{~km}^{2}$, and the sinking velocity is up to $10 \mathrm{~cm} \mathrm{yr}^{-1}$ in some zones, the main concern for valley inhabitants and local government is the occurrence of subsidencerelated cracks and failures, which are developed in the surface terrain and damage buildings and infrastructure. In order to face this problem, the state government of Aguascalientes set up in 1994 an interinstitutional committee which is integrated by four working groups: (1) technical studies, (2) equilibrium of the aquifer, (3) normativity and cartography, and (4) attention to damaged infrastructure. Each working group integrates several public and private agencies whose activities are influenced by the in-progress subsidence process. Federal, state and municipal water management agencies, as well as government bureaus of urban planning and public works are included in the committee. Also, the state university and some professional state associations such as civil engineers and earth sciences engineers are actively involved in the committee, along with the National Institute of Statistics, Geography and Informatics, which is the federal agency addressed to produce official cartography in Mexico. Some agencies participate not only in one working group but in those that fall in their interest, therefore, many agencies are contributing to several working groups objectives. In this work, we present a summarize of the work developed for the committee since its creation, and about its evolution and current organization. It is presented an analysis and discussion of the changes that the committee has experienced in their objectives and applied methods to address the evolution of the fissuring problem, and how their results have helped to prevent and to mitigate the land subsidence effects. Also, the mechanisms implemented to inform to the general public about the subsidence process and its effects; besides of the expected challenges that the committee will enfaces in the near and far future. This work intends to share the experiences of the committee hoping to be useful to other government agencies and earth scientists dealing with the land subsidence problem.
\end{abstract}




\section{Introduction}

Land subsidence and related surface faults an ground fissures have been investigated and documented in several regions worldwide, and is a main topic of discussion at several scientific conferences (NISOLS, 2015). In México, the alluvial and lacustrine basins of the central plateau as Celaya, Querétaro, San Luís Potosí, Morelia, Toluca and Aguascalientes, are the places where this problems of ground deformation and surface faulting were first reported (Aguirre-Díaz et al., 2000; Calderhead et al., 2011; Garduño-Monroy et al., 2001; Julio-Miranda et al., 2012; Pacheco-Martínez et al., 2006, 2013; Trujillo-Candelaria, 1991). Nowadays land subsidence due to groundwater withdrawal and related ground failures affect close to 100 cities along México (Figueroa-Miranda et al., 2018).

In all these places, several local government agencies deal with the problem focusing on those tasks related to their subject of competence. For example, State Agencies for Civil Protection, who are the responsible for preventing and managing the risk situations in each state of México, have undertaken several efforts to manage the related risk to land subsidence. However, these agencies do not generate information to be directly used in urban planning and development, nor to be used by engineers and builders. Therefore, there is no direct and effective collaboration or feedback between all the governmental agencies whose activities are influenced in different grade for the land subsidence problems.

In this work, we present the activities developed for the Committee for managing the risk by Faults and Cracks due to subsidence in Aguascalientes State since its creation, and how it is organized. It is presented an analysis and discussion of the changes that the committee experienced in their objectives and applied methods to address the evolution of the ground fissuring problem, and how their results have helped to prevent and to mitigate the land subsidence effects. Also, the mechanisms implemented to inform to the general public about the subsidence process and its effects; besides of the expected challenges that the committee will enfaces in the near and far future.

\section{Land subsidence in Aguascalientes Valley}

Aguascalientes Valley is in the Mexican state of the same name at the central part of Mexico (Fig. 1). The valley is within a tectonic graben defined by two north-south-trending normal faults. This tectonic depression has been filled by tertiary and quaternary alluvial and fluvial sediments with a low-to-medium degree of consolidation forming the aquifer system. The climate in the Aguascalientes Valley is arid to semiarid, which in combination with a lack of surficial water flows and surficial water reservoirs, have promote that the groundwater is the main source of water not only for agriculture, but also for municipal and industrial consumption.

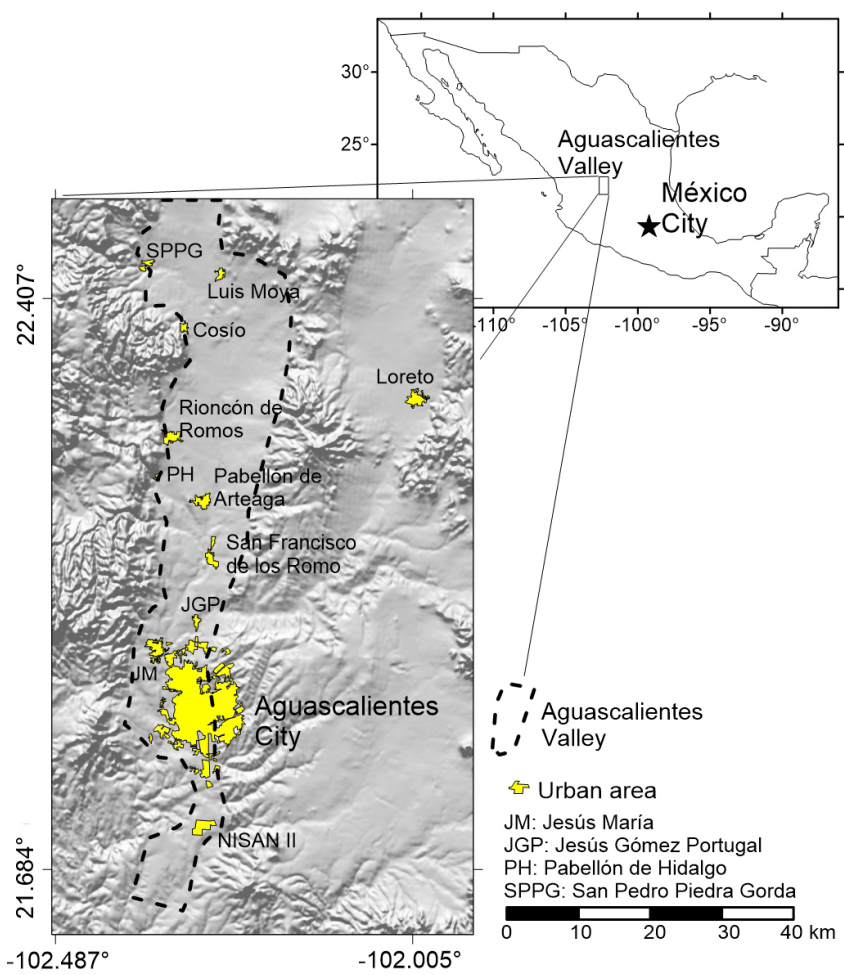

Figure 1. Location of Aguascalientes Valley in the context of Mexico, and location of the main settlements into the valley. Modified from Pacheco-Martínez et al. (2015).

Until the 1940's, the city satisfied its demand of fresh water from the springs and handmade shallow wells which does not exceed more than $30 \mathrm{~m}$ depth, taking water from the regional aquifer system. Groundwater pumping was initiated in the 1940s mainly for municipal and industrial uses, but water demand grew in the ensuing years and pumping became intensive during the 1970s, as a consequence of the industrialization of Aguascalientes City, and due to the opening of new lands for agricultural purposes (Pacheco-Martínez et al., 2013).

As the valley population grew, groundwater pumping increased causing a drop of the regional water table triggered a land subsidence process in the entire valley becoming a hazard for properties, inhabitants and the environment.

The first observations of the effects of land subsidence in the valley occurred at the beginning of 1980's. Damages to the constructions and infrastructure, mainly roads and pipelines, due to reactivated and new surface faults and ground fissures were documented (Aranda-Gómez, 1989). For 2015, 208 surface faults and fractures had been mapped throughout the entire Aguascalientes valley with an accumulated length of $290 \mathrm{~km}$, affecting 1865 buildings mainly housings, from which 1438 of those are located within the city of Aguascalientes, (Pacheco-Martínez et al., 2013, 2015). Nevertheless, the terrain level lowering was noticed until 1990 by means of records of a GPS station placed a 


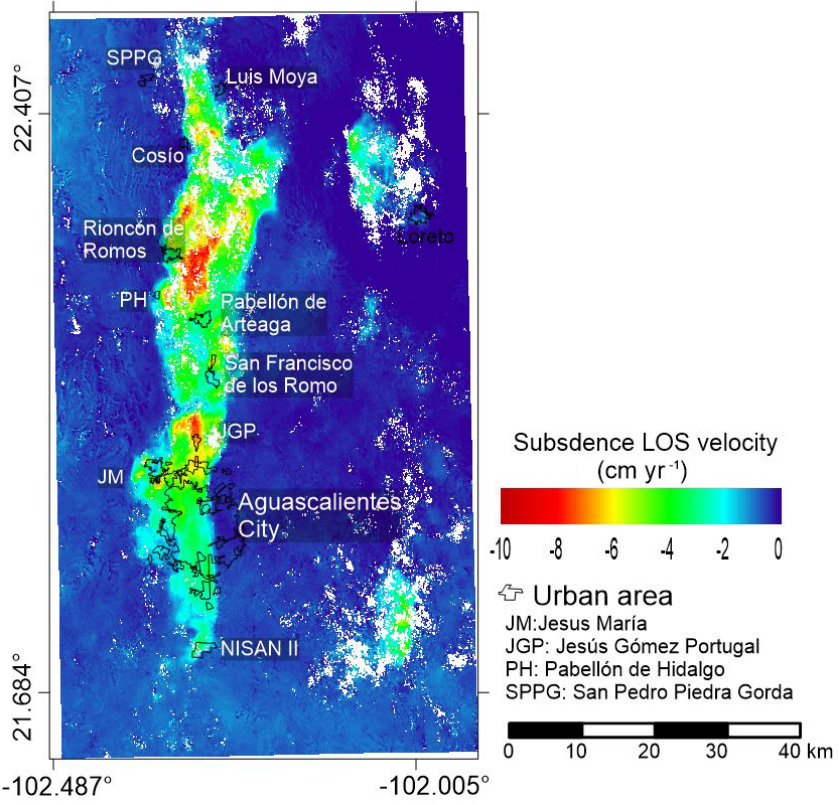

Figure 2. Subsidence LOS velocity map of Aguascalientes valley. Modified from Pacheco-Martínez et al. (2015).

building at the south of the city of Aguascalientes. Those records showed that the valley has lowered at the GPS location to a rate up to $6.4 \mathrm{~cm} \mathrm{yr}^{-1}$, accumulating $1.6 \mathrm{~m}$ in 25 years from 1990 to 2015 .

More recently, the total area affected by land subsidence was determined by means of SAR images analysis (Fig. 2) computing $940 \mathrm{~km}^{2}$ of terrain affected by subsidence, and documenting subsidence velocities up to $10 \mathrm{~cm} \mathrm{yr}^{-1}$ (Pacheco-Martínez et al., 2015)

According to National Institute of Statistics and Geography (INEGI), the state of Aguascalientes had a population of 338000 inhabitants in 1970, which quadrupled in 40 years, reaching 1312000 inhabitants in 2015, of which $88 \%$ live in the Aguascalientes Valley with a majority of them (70\% of the total) settled in the Aguascalientes City.

Recently, a new episode of industrial growth is ongoing with the opening of several industrial parks at the south of the valley, which in turn triggered an increase in the population settled in the valley as well as the necessity for new urban developments for housing, therefore, it is expected a sustained growth in the demand of groundwater, besides an intensification of the land subsidence process.

As it can be seen, the problems related to land subsidence is multifactorial and must be faced it with multidisciplinary strategies. It is an issue of scientific study but also is a concern to local governments due to the social implications it has. As a consequence, the management of land subsidence problems gather professional of diverse disciplines, such as earth scientist to explain the phenomenon, but also technicians involved with urban planning and development; civil
Committee of geological faults and cracks of aguascalientes

\begin{tabular}{|c|c|c|c|}
\hline & \multicolumn{2}{|c|}{ General coordination } & \multirow[b]{2}{*}{ WG4 } \\
\hline WG1 & WG2 & WG3 & \\
\hline $\begin{array}{l}\text { Technical } \\
\text { studies }\end{array}$ & $\begin{array}{l}\text { Equilibrium of } \\
\text { the aquifer }\end{array}$ & $\begin{array}{l}\text { Normative and } \\
\text { cartography }\end{array}$ & $\begin{array}{l}\text { Attention to affected } \\
\text { infrastructure }\end{array}$ \\
\hline \multicolumn{3}{|c|}{ Federal agencies } & State university \\
\hline \multicolumn{2}{|c|}{ Estate agencies } & \multicolumn{2}{|c|}{ Professional associations } \\
\hline
\end{tabular}

Figure 3. Structure of the committee.

engineers and architects responsible to develop safe constructions and infrastructure as well as maintain it in good conditions of operation; lawmakers for developing the suitable regulations in all the maters having participation on this problematic, etc.

\section{Formation and structure of the committee}

The committee of Geological Faults and Cracks of Aguascalientes State (CIFGGEA) arose in September 2003, after a ground failure appeared triggered by an intense rainfall causing damage to several houses and to the pavement of an avenue at the neighborhood locally called "Casa Blanca" at the south of the city of Aguascalientes. The first objective of the committee was to unify criterion and methods of study the phenomenon in order to inform the citizens and propose remediation measurements for the damaged caused for the fault.

The proposal of the creation of the committee was formulated for the Ministry of Infrastructure and Communications of the State of Aguascalientes, it was legally established in 23 February 2004 after its discussion and approbation in the local congress.

The committee is organized in four working groups (Fig. 3) that are:

- Working group 1 technical studies. Headed by the $\mathrm{Au}$ tonomous University of Aguascalientes (UAA). It is the working group responsible to propose and coordinate the carrying out of the needed technical studies to manage the land subsidence related risk over the constructions, infrastructure, and population

- Working group 2 Equilibrium of the Aquifer. Lead by the bureau for sustainability, environmental and water affairs (SSMAA). They are responsible for the water management focusing on achieving sustainable use of the groundwater for stopping the groundwater level lowering of the aquifer system.

- Working group 3 Normative and Cartography. This working group is coordinated by the state bureau for planning and territorial ordering (SEGUOT), is focused 
to map the new surface faults and ground fissures that are spreading, as well to map those that are enlarging, in order to maintain updated the terrain discontinuities cartography. The working group is also responsible to propose changes in the local laws related to the subsidence problem, mainly those related to urban planning and development, and new constructions in zones affected surface faults and ground fissures.

- Working group 4 Attention to Affected Infrastructure. Lead by the ministry of public works of Aguascalientes state. They are responsible for repairing the damaged infrastructure such as roads pavement and sidewalks, utility pipelines, but they also advise people about the potential risk related to subsidence for real state acquisition purposes.

At the beginning, the four working groups were coordinated by the Water Institute (currently SSMAA) which was the state government office for water affairs, but since 2016 the committee is coordinated by the state bureau for planning and territorial ordering (SEGUOT).

The committee is supported by federal, state and local agencies dealing with water management, urban planning and development, risk management, public works, elaborating the official cartography of México; as well is supported by local professional associations of civil and geotechnical engineers, architects, environmental geologist and geophysicist; and by the Autonomous University of Aguascalientes. Each one of these institutions can collaborate in one or more working group, it depends on how much the phenomenon and related problems influence in its ambit of competence and responsibilities. For that, there are a representative permanent and a substitute one by each institution in each working group.

Nowadays, each working group meets separately bimonthly to plan the next two months of works and to review the accomplishments of the works previously programed, A plenary meeting is carried out also bi-monthly which is attend for the four working groups. In this meeting, the progress in the annual working agenda is reviewed, and feedback about the works in progress from all the working groups is given.

\section{Activities and achievements}

The fist activities the committee had to carry out after its creation in 2004 was to explain why and how the Casa Blanca fault was produced, and what measurements they had to take to repair the damaged caused. After this moment of crisis, the committee focused on mapping all the discontinuities and publish the first official cartography of the ground failures. This first version was published in 2005, in a pressed version of twelve maps scale $1: 50000$, and covered only the ground failure trace through the Aguascalientes city and Jesús María city, the main settlements due to their population in that time.

After this first version of ground failure maps, in 2006 a digital version called Soil Discontinuities Digital System (SIDDIS) was released as a Geographic Information System for being installed on a PC, and was updated several times in the next years. It covered already the complete urban zone of Aguascalientes City and Jesús María city with all the ground failures mapped by the damaged caused to the buildings and street pavement. Those digital versions also included photographs and data helping to localize the ground failure in situ, for example, it included information of the distance between the terrain discontinuity trace to the nearest corner. The last SIDDIS version was released in 2011, after that, the cartography of the entire valley was released online in 2012 as the Information System of Geologic Faults and Fissures (SIFAGG), which contain a kml layer that can be consulted on a Google Map windows at: http: //www.aguascalientes.gob.mx/sop/sifagg/web/mapa.asp (last access: 13 March 2020).

Since the committee was created, a concern of the participants was to include restrictions and requirements to the new urban develops and new constructions in order to avoid constructions over the trace of ground failures avoiding legal disputes and economic losses for future owners and urban project developers.

Currently, several recommendations and requirements for new construction projects have been incorporated in the Urban Code for the Aguascalientes State. The most relevant are:

1. The Certification of proficient professionals in geology or geophysics is mandatory for all those who offer consultant services on ground failure assessment for construction purposes.

2. Municipalities are required to prepare and publish ground faulting maps.

3. The normative includes a risk zoning based on the proximity to mapped ground faults.

4. The Code requires constructors to present geophysical or geological studies prepared by the certificated geologist or geophysics in order to obtain a construction license.

\section{Incoming challenges for the committee}

One of the concerns to the CIFGGEA members is continuity and financial support. Even though the committee is legally established and recognized by authorities, in a country as México, the priorities in the state public agenda can change every 6 years with the government elections. Furthermore, the committee does not have own fund, its operations depend on how much time is commissioned for the participants by their adscription institution to collaborate in the activities of the workings groups, as well depend on the extraordinary 
funds that the general coordinator (SEGUOT) may get for the committee operations.

A challenge for the committee is the developing and adaptation of methodologies for reaching a complete risk management as well its implementation and evaluation. Even though the committee has progressed in this working line, mainly due to the works of University Autonomous of Aguascalientes, more research is needed to accomplish this main objective of the committee.

\section{Conclusions}

The committee of Geological Faults and Cracks of Aguascalientes State is a pioneer as organization for face the problems related to land subsidence since the focus of several disciplines and diverse grades of specialization to get with practical information for associated risk management.

The organization of the committee split into four groups allow generate information and transfer it to users for planning and management in several areas from urban planning to environmental protection, beside the generation of recommendations to modify local laws to better face the subsidence problematic. Therefore, this working organization manner could be helpful in other places with land subsidence problems.

Data availability. No data sets were used in this article.

Author contributions. JPM developed the main idea and wrote the paper. MHM contributed with information on groundwater and reviewed the final version of the manuscript. MEZdL contributed with information on the history of subsidence in aguascalientes valley. NGC reviewed the description of the geological setting of Aguascalientes valley. JAOL contributed with information on the effects on constructions of the land subsidence. OVG facilitated the collaboration of the University subsidence working group in the committee. ARC promoted the incorporation of the University subsidence working group to the committee.

Competing interests. The authors declare that they have no conflict of interest.

Special issue statement. This article is part of the special issue "TISOLS: the Tenth International Symposium On Land Subsidence - living with subsidence". It is a result of the Tenth International Symposium on Land Subsidence, Delft, the Netherlands, 17-21 May 2021.

Acknowledgements. Thanks to all the members of other agencies who collaborate in the working group of technical studies by their contributions in the daily work of the CIFGGEA.
Financial support. This research has been supported by the Universidad Autónoma de Aguascalientes through the funding to the research project PIIC20-1.

\section{References}

Aguirre-Díaz, G. de J., Zúñiga-Dávila Madrid, R., PachecoAlvarado, F. J., Guzmán-Speciale, M., and Niero-Obregón, J.: El graben de Querétaro, México, Observaciones de fallamiento activo, GEOS, 20, 2-7, 2000.

Aranda-Gómez, J. J.: Geología preliminar del graben de Aguascalientes, Rev. Mex. Cienc. Geol., 8, 22-32, 1989.

Calderhead, A. I., Therrien, R., Rivera, A., Martel, R., and Garfias, J.: Simulating pumping-induced regional land subsidence with the use of InSAR and field data in the Toluca Valley, Mexico, Adv. Water Resour., 34, 83-97, https://doi.org/10.1016/j.advwatres.2010.09.017, 2011.

Figueroa-Miranda, S., Tuxpan-Vargas, J., Ramos-Leal, J. A., Hernández-Madrigal, V. M., and Villaseñor-Reyes, C. I.: Land subsidence by groundwater over-exploitation from aquifers in tectonic valleys of Central Mexico: A review, Eng. Geol., 246, 91-106, https://doi.org/10.1016/j.enggeo.2018.09.023, 2018.

Garduño-Monroy, V. H., Arreygue-Rocha, E., Israde-Alcántara, I., and Rodríguez-Torres, G. M.: Efectos de las fallas asociadas a sobreexplotación de acuíferos y la presencia de fallas potencialmente sísmicas en Morelia, Michoacán, México, Rev. Mex. Cienc. Geol., 18, 37-54, 2001.

Julio-Miranda, P., Ortíz-Rodríguez, A. J., Palacio-Aponte, A. G., López-Doncel, R., and Barboza-Gudiño, R.: Damage assessment associated with land subsidence in the San Luis PotosiSoledad de Graciano Sanchez metropolitan area, Mexico, elements for risk management, Nat. Hazards, 64, 751-765, https://doi.org/10.1007/s11069-012-0269-3, 2012.

NISOLS: Prevention and mitigation of natural and anthropogenic hazards due to land subsidence, Ninth International Symposium on Land Subsidence (NISOLS), edited by: Daito, K. and Galloway, D. L., Copernicus Publications, Nagoya, Japan, 2015.

Pacheco-Martínez, J., Arzate-Flores, J., Rojas, E., Arroyo, M., Yutsis, V., and Ochoa, G.: Delimitation of ground failure zones due to land subsidence using gravity data and finite element modeling in the Querétaro Valley, México, Eng. Geol., 84, 143-160, https://doi.org/10.1016/j.enggeo.2005.12.003, 2006.

Pacheco-Martínez, J., Hernandez-Marín, M., Burbey, T. J., González-Cervantes, N., Ortíz-Lozano, J. Á., Zermeño-DeLeon, M. E., and Solís-Pinto, A.: Land subsidence and ground failure associated to groundwater exploitation in the Aguascalientes Valley, México, Eng. Geol., 164, 172-186, https://doi.org/10.1016/j.enggeo.2013.06.015, 2013.

Pacheco-Martínez, J., Cabral-Cano, E., Wdowinski, S., HernándezMarín, M., Ortiz-Lozano, J. Á., and Zermeño-de-León, M. E.: Application of InSAR and Gravimetry for Land Subsidence Hazard Zoning in Aguascalientes, Mexico, Remote Sens., 7, 1703517050, https://doi.org/10.3390/rs71215868, 2015.

Trujillo-Candelaria, J. A.: Fallamiento de terrenos por efecto de la sobreexplotación de acuiferos en Celaya, Guanajuato, México, Asociación Internacional de Hidrologos, Puerto de la Cruz, Islas Canarias, España, 175-178, 1991. 